\title{
6
}

\section{A Moral Economy of the Transnational Papua New Guinean Household: Solidarity and Estrangement While 'Working Other Gardens'}

\author{
Karen Sykes
}

\section{Introduction}

Transnational Papua New Guinean (PNG) household members provide for each other while making new forms of traditional marriage, often resulting in changes to their access to land in their homelands in PNG. They capture the sense of that experience of migration away from clan lands with the idiom 'working other gardens', by which they mean they have migrated from PNG to 'other gardens'. Although they sustain their household's livelihood as employees of firms and as parents of students, public speculation about Papua New Guineans' reasons for taking up residence in Australia focuses wrongly on their geopolitical demographics rather than this moral economy of the transnational PNG household. Neither the state and its agencies nor the independent service providers, who assume the political economy of PNG-born residents in Australia is precarious given the transience and landlessness of the members of this community, grasp the moral economy of the transnational household. Contrary to the precarious political economy imagined by representatives 
of the state, ethnographic research reveals a moral economy of resilient solidarity within the transnational household. PNG women live at its centre, often having multiple residences in PNG and Australia. Nevertheless, it is one within which disaffected household members might find they are estranged from traditional land.

\section{'Working Other Gardens'}

I learned to turn my attention to the experiences of PNG women in Australia, and away from census data and the moral judgements made about their households, during a short fieldwork trip in 2011. I had made a journey with several PNG women from Cairns, in Queensland, to Darwin, in the Northern Territory. Among other plans, we hoped to view the 10,000-year-old petroglyphs in Kakadu National Park and to visit some old friends settled there. We were guests for an evening in the household of a PNG woman whose husband worked in the uranium mine several hours out of the city. Our host had once hailed from Western Province, PNG, as had another family (from the mouth of the Fly River) who had travelled with us from Queensland. Another guest in the house that evening had come to Darwin from PNG to attend a technical education college for a three-month course. He arrived with two other Papua New Guineans from Enga who had been recovering in a Darwin hospital, receiving treatment for injuries sustained on a mining site at their employer's expense. That night, I joined the gathering with my three friends who had been born on the New Guinea islands.

I asked the PNG women and men present that evening how such a disparate group of Papua New Guineans had come to be living in Australia, how they sustained their lives there and what they made of their experience of doing so. I posed my questions to the group over a lateafternoon meal, which was served in traditional style: generous amounts of root vegetables - sweet potatoes, taro, cassava and sago-with portions of roast chicken. They were bemused by their realisation that they were eating many of the same foods enjoyed for centuries, and I asked them to clarify their thoughts. My companions answered, but talked more about the deep past than the present. They spoke of their ancestors, the Pacific navigators who had accomplished one of the greatest triumphs over space and time of any migration in global history, moving westward out of South-East Asia to Madagascar and eastwards to Rapanui (Easter Island) 
over 10,000 years ago. They spoke of seagoing canoes peopled by their ancestors and loaded with bundles of taro and yams, models of which stood in the Northern Territory museum nearby. They spoke of the deep history of their ancestors, who, they believed, had had the ability to make a life wherever they landed-not by marine crafts but by expert horticulture. They also remembered the modern migrations of workers to plantations in Queensland, and recounted stories of meeting the descendants of these men and women. Perhaps the authenticity of these ancient and modern stories rested more on my friends' view of their own peripatetic lives in the present than on the archaeological record? Taking new jobs, moving to a new house and even visiting relatives across many Pacific islands had remained a common habit throughout their history.

In this introductory section, I have described my understanding of a gathering of Papua New Guineans in Australia. How that fieldwork experience reconfigured my research questions follows in the rest of this chapter. I learned that the twenty-first century form of association, the modern PNG household, emerged out of the migration of household members from PNG to Australia, Europe, South-East Asia and the Americas. However, the principal destination for the last four or five decades has been Australia, where increasing numbers of PNG women have settled with their husbands and children. I also learned that many migrant PNG households in Australia are composed of the descendants of two or more generations of marriages across the language or cross-ethnic groups of multicultural PNG. At best, they had complex means of access to their clansperson's land in PNG; at worst, no rights to use it. How they came to migrate to Australia and find other work there arises from their generational histories, rather than only from contemporary, individual motives. Their ancestors' intention to work 'other gardens' wherever they landed to make a good life together in the future appealed to my friends' sense of their current moral reality of making a livelihood in a widely dispersed network of household members; they used the idiom to capture the character of their new livelihoods in Australia, where they now 'work other gardens' because they must do so. 


\section{The Limits of Geopolitical Accounts of the PNG Transnational Household}

The moral economy of the transnational PNG household was unknown to local government and businesses. When local councils and their business partners in Queensland began to investigate these further it was because they most often relied on the census data, which was too thin to provide a picture of how the transnational PNG household lived. Most often, business and government officials mistook the particularities of the PNG householder's moral economy for their response to the loss of more general economic rights. The government officials raised the ethical principle that communities must not only survive, but also thrive and flourish. They raised concerns with the PNG householders rights to thrive within the optical economy of the region, which were based on the assumption that members had a right to make a livelihood based on access to residence, work, and social care. I was encouraged by the agents of local government and business to enrich their demographic picture of the transnational PNG household so that they might assist the PNG community to make a good life together.

Ethnographic fieldwork yields knowledge that is different from the information that methods like census data collection and analysis allow. My research among transnational PNG families had begun simply enough with my inquiry into the PNG community in Australia and how they constituted their relationship with each other there. I began in their households in Far North Queensland, a region of more than 225,000 residents in the Australian state of Queensland. The total number of Papua New Guineans there is unrecorded in the census because their residency is so fluid and their identity unfixed. Many people I knew kept one home in the political jurisdiction of Far North Queensland because of its proximity to PNG's national capital, Port Moresby, a mere one-hour flight away. Often, they also had a home in Port Moresby, where some household members lived; perhaps a third had another home in either a more distant part of Australia or in a PNG province. However, the PNG families I worked with in greater Cairns showed me that the household was transnational because it was defined by how its members related to each other. I came to see that the strength of kinship and friendship connections across distances mattered more to their identity as Papua New Guineans than the location of their residences. 
My first acquaintance with the transnational household had been in the 1990s when I broke my travels to PNG in Cairns to visit people I had first met in their PNG village. Often the Australian-residing arm of the household asked me to carry messages to relatives in towns or villages in PNG, but I did not realise that fluidity is deeply characteristic of the PNG household until I settled in Far North Queensland myself in 2012. Beginning in the greater Cairns area, which had a population of about 50,000 people, I mapped those PNG households geographically to other Queensland towns and cities and to Australian cities in different states, as well as to the PNG towns and cities where household members owned or rented other houses. This was daunting at first but became less so as I followed the connections they had already made, thereby coming to see the transnational household in distinctly PNG terms, rather than geopolitical ones.

I found that PNG households typically settled in Cairns for several months, after which their members made longer visits to other homes in PNG and Australia. It can be said that, rather than the physical residence itself constituting the household, it is the PNG women who form the centre point of these large extended households of relatives and 'friends' for whom they choose to care, and who might be called, in Tok Pisin, wantoks. I met with the members of approximately 60 households of this character between 2011 and 2014. All the households in my survey centred upon relationships between a PNG woman, her clanspersons and her in-laws, or affines. Her husband might have been white Australian or European, or identified as Chinese or Malaysian. Comparatively few PNG women were married to men from other Pacific island nations, but many had married a PNG man, often from a different language group, or an entirely different PNG region. The PNG woman's point of view of the domestic moral economy of the transnational household often encompassed concerns with household and financial debt, as well as 'marriage debt', as I describe in two cases of mortgages held by transnational PNG families (Sykes, 2013). Certainly, a PNG woman might feel challenged to sustain the members of such a household and, in coming to define the ground rules for inclusion in it, she might exclude certain wantoks and relatives from care by the household, thereby limiting the demands made on her and the household.

Just as PNG women were concerned about the resilience of their transnational households, so too was regional government. However, by contrast with the point of view of PNG women, which centred on relations 
between households (i.e. the domestic moral economy), the perspective of local service providers and regional government was something like 'geopolitical-centric', following the assumption that simple residence in the region is the most significant factor in understanding PNG households. This assumption confounded service providers' ability to acknowledge and report on the transnational quality of these households. They were often heard to say that the PNG population of greater Cairns was 'a very roughly estimated number in the neighbourhood of something between five- and eight-thousand people'. Their geopolitical-centric perspective focused on Cairns being home to the highest concentration of PNG households in Australia, with it being commonly rumoured in business and government that the Cairns-area population represented 'between a quarter or a half of the total number of Papua New Guinean people resident in Australia as of 2011', but there were not official data to show it. The more that officials tried to clarify the census data, the less convincing was their hold on any significant knowledge of Papua New Guineans in Australia. As I learned to be sympathetic to the trials of interpreting the lifestyle and residence patterns of a somewhat mobile form of household, I also realised that census data are not a good guide to how Papua New Guineans thrive in Australia; the data are not even a measure of how many people live in such households. That requires an account of the moral economy of the PNG transnational household, which I describe below.

Closer analysis of census data shows how little value it brings to the clarification of even the geopolitical profiles of people of different ancestries. Despite not providing the solid evidence needed for developing shared political visions or social planning, a powerful moralising discourse emerged around census data. Regional politicians mapped a trend across Australian census years that showed an increase in the absolute number of people declaring themselves to be PNG-born residents of Australia, with the two largest increases coinciding with particular events in immigration policy. Table 6.1 shows that the largest increase in numbers occurred in 1976, the year after PNG independence. This was when Australian families returned to Australia after decades of working in PNG, started new businesses and took up jobs in various Australian states, often in Queensland. The increase in 2006 coincided with shifts in Australian immigration policy regarding the issuing of education visas for PNG children. Whereas in past decades, students had come to Australia on scholarships offered by the Australian Government, in the twenty-first century, PNG children were given visas for study, with one PNG adult 
offered a guardianship visa to accompany them. The significance of official moralisations about these historical developments is clearer when examined at the level of the household.

Table 6.1: PNG-Born Migration to Australia, 1954-2011

\begin{tabular}{|l|l|}
\hline Census Year & Number \\
\hline 1954 & 1,723 \\
\hline 1976 & 15,562 \\
\hline 2006 & 24,024 \\
\hline 2011 & 26,787 \\
\hline
\end{tabular}

Source: Department of Immigration and Citizenship, Australia (n.d.).

Despite official trust in these figures, they overstate the number of PNG migrants, as many of those PNG-born migrants in Australia are the children of Australians who were working in the former territories of PNG. In addition, many hundreds of people who are recorded in the 2011 census as PNG-born residents were those temporarily visiting (six to 12 weeks) as adult students at Australia's many technical and further education colleges. In short, the numbers do not record merely residents of PNG descent; nor do they distinguish longer term or permanent residents.

To better grasp the aggregate size and significance of PNG-born migration, census data on 'ancestry' was also gathered. Notably, this data were volunteered: it was not required. In the Australian census, a total of 15,460 responses indicated PNG ancestry. However, it must be remembered that this is not the same as saying that 15,460 persons identified as having PNG ancestors. There are several reasons for this. First, by 'ancestry' the census question meant the birthplace of the respondent's parents or grandparents, and not their nationality or 'race'. For example, as I learned during my ethnographic inquiries, a respondent with a parent born in PNG would list PNG ancestry even if that parent were the child or even grandchild of (white) German residents in PNG. Second, the voluntary nature of responses necessarily skewed the results, making them non-representative; many people simply did not respond to the question (i.e. they listed none of their ancestries). Third, those who did respond to this question could identify either two ancestries or one, as they wished. For all these reasons, the Department of Citizenship and Immigration could not clarify just how many people chose to respond with information 
about both, one or none of their parents and grandparents. ${ }^{1}$ Hence, those analysing the data were warned not to divide the number of respondents into the aggregate number of responses because it would not determine how many PNG-born people also identify as having PNG ancestry.

Of all the responses to the question about respondents' ancestry, the responses given by people who also identified as PNG-born can be expressed in tabular form. Table 6.2 shows that of the major ancestries named by those who were born in PNG, only 23 per cent indicated PNG ancestry, a raw number of 8,752 out of 37,625 responses. Notably, 'other ancestral responses' has the largest percentage of all responses, being the total number of responses that do not name the top four named ancestries of the PNG-born: Papua New Guinean, Australian, English and Chinese. Table 6.2 shows the aggregate number of responses to this question.

Table 6.2: Ancestry Responses of PNG-Born Migrants, 2011 Census

\begin{tabular}{|l|r|r|}
\hline Ancestry responses & Number of responses & \% all responses \\
\hline Papua New Guinean & 8,752 & 23 \\
\hline Australian & 7,313 & 19 \\
\hline English & 6,736 & 18 \\
\hline Chinese & 2,972 & 8 \\
\hline Other & 11,852 & 32 \\
\hline Total Responses & 37,625 & 100 \\
\hline
\end{tabular}

Source: Department of Immigration and Citizenship, Australia (n.d.).

Quite wisely, the compilers of the data warn against translating aggregate responses into percentages of people, and percentages into absolute numbers of people of PNG descent. Hence, the number 8,750 is neither an absolute nor approximate number of people of PNG descent in Australia. Instead, it represents the aggregation of responses to the category 'PNG ancestry'.

1 There is no analysis that can reveal how many people surveyed actually listed PNG ancestry, let alone were actually of it. Given that the census counted 26,787 people who identified as PNG-born, their total possible numbers of ancestry responses, at the limit of two per respondent, would have been 53,574. However, the total ancestry responses of the PNG-born were 37,625. Not surprisingly, perhaps, this figure is the aggregate of responses that listed one or two ancestral birthplaces of parents and grandparents. 
'PNG-born and resident in Australia' is a fuzzy category, one that offers little clarity about those whose lives it describes, except that Queensland is their favoured destination, as Table 6.3 shows.

Table 6.3: Geographical Distribution of PNG-Born, 2011 Census

\begin{tabular}{|l|r|r|}
\hline State & Number of PNG-born & \% total PNG-born \\
\hline Queensland & 14,500 & 54 \\
\hline New South Wales & 5,428 & 20 \\
\hline Victoria & 2,534 & 10 \\
\hline Western Australia & 1,763 & 6 \\
\hline Other & 2,562 & 10 \\
\hline Total & 26,787 & 100 \\
\hline
\end{tabular}

Source: Department of Immigration and Citizenship, Australia (n.d.).

However, it remains as difficult in this as in other tables to understand to whom the figures refer. In the course of my fieldwork, I met many white Australians who invested in Queensland farms and small businesses after the sale of plantations in PNG. By their own account, they preferred to resettle in Queensland because they could more readily gain access to their remaining business investments and personal commitments in PNG.

In the course of my fieldwork, I heard how the Far North Queensland regional government and service providers were increasingly perplexed by the disjuncture between reports of an extensive PNG presence in their region and their actual experience; they simply did not meet as many Papua New Guineans as the census figures suggested they might. At first, they set out to find more PNG people. When they were unable to do that they came to doubt the census figures. Some government officers admitted that they had misread the figure of 26,787 as the measure of PNG migrants in the country, not realising that it was an aggregate that included many more people who were born in PNG but of Australian ancestry and citizenship. Others misread the number of responses identifying PNG ancestry for the number of individuals of PNG descent. The next section shows that the Australian Government Department of Citizenship and Immigration correctly warned users of their data to take care when extrapolating from it to comment about the PNG community. 


\section{Moral Economy Versus Political Economy in the PNG Transnational Household}

It is common to use census data to describe the political economy of a population. However, the case of the PNG transnational family is better grasped via an account of their moral, rather than political, economy, which requires ethnographic methods. In this section, I show how geopolitically informed census data misshaped knowledge of the political economy of the PNG transnational family and led service providers, business managers, financial institutions and government officers to err through speculations about the meaning of the numbers, a form of insight called 'quantitative gossip' by E. P. Thompson (1993, p. 413). Searches were made by officials of the registration records of the Queensland Department of Education and those of the state's health services for better evidence of the needs of the community, and they contacted representatives for the Pacific Islanders in the region to elaborate on these needs. However, searches of the property register, in particular, generated morally charged debate about the make up and political economy of the PNG household. Following an overview of some of the first responses to the census by health and education offices, as well as to the Queensland property register, I focus on the moral economy of the PNG household as the lived reality within which PNG livelihoods are made.

The Queensland Department of Education records the arrival of new students from PNG every school year, but it does not have a distinct record of PNG households that have settled permanently in Australia. In 2011, 30 PNG students began studies in Far North Queensland for the first time; in 2014, that number more than doubled, with the arrival of over 30 students on an Ok Tedi company scheme, accompanied by family members. The department's figures represent new migrations in the hundreds each year from 2011 to the present, as parents and their non-school age children have taken up residence.

The Queensland Department of Health wanted better information about those who called a parent or a grandparent PNG-born because the census data was 'too soft' to provide them with good evidence for decision-making. They commissioned an independent study of the PNG community's health needs and held focus group meetings in Townsville and Cairns, where it believed the greatest number of PNG-born people 
lived. A survey of stated needs, based on 15 respondents from each city, showed that diabetes and heart disease were the most commonly occurring non-communicable diseases suffered by members of the community, just the same as for non-PNG, white Australians. Citing the importance of meeting Pacific Islanders' health needs, the department hired a health officer from PNG to work with Papua New Guineans in Queensland. They made special attempts to develop links with PNG women, who were thought to be vulnerable in Australia, and who were also considered the key to the wellbeing of PNG networks in the region. On the latter point, they were right.

Individual public officials, service providers and business people reflected on how the figures did not fit with their experience; they did not see as many PNG-born residents on the street as census data suggested they would. PNG neighbourhoods do not exist in the greater Cairns region, nor can any distinctive pockets or enclaves be found in the wider political region of Far North Queensland. Despite acknowledgement of the vagueness of the census data, Cairns residents were still surprised by the extent of PNG involvement in local home ownership. In 2010, the Cairns Post reported that research into the Queensland property register showed Papua New Guineans investing more money in Far North Queensland property than any other foreign buyer, except those from Singapore who led in land purchases with AUD11.5 million covering 11.1 hectares. However, PNG purchases totalled 181 properties covering 10.3 hectares by comparison to Chinese purchases of 19 properties covering 108 hectares (Dalton, 2014, p. 13). The most common purchase was a three-bedroom family home, even if the common wisdom was that an office building would provide a better return on a comparable investment.

In the first analyses by journalists, most PNG activity on the property market was seen to be driven by the purchase of personal residences valued under AUD500,000, rather than for the purchase of housing as an asset or financial investment. Notably, Queensland house prices are similar to those of comparable houses in the neighbourhoods of Port Moresby, where many professionals and civil servants live. When families have a house in PNG and another in Queensland, often the Queensland house is of a lower price and in better repair than the Port Moresby one. Some families had simply sold a high-priced house in the old suburb of Boroko and purchased one in Cairns. 
Rumours of 'corruption' and speculation about the morality of PNG purchases in Cairns spread among white Australians, as some property purchases appeared to be way beyond the means of buyers. Some white Australians made suspicious comments about property investments by PNG political leaders or businesspeople simply because they handled contracts for the royalties from mining-industry operations on traditional land. However, these claims were hard to substantiate. Papua New Guineans shared their suspicions and doubts with me, but also questioned the verity of the stories in circulation. For example, Papua New Guineans in Cairns protested that the price tags on their Australian homes were much lower than those on good-sized lots in Port Moresby, where old colonial housing (c. 1950-70s) built on quarter-acre lots sold for hundreds of thousands of PNG kina, often triple the value of the same period-style house on the same size lot in Cairns. They admitted that the allegations of corruption could not be proven or disproven without a full inquiry. Some civil servants faced the possibility of a tribunal in their workplace that would investigate those personal financial arrangements that were not usually publicly known. Rumours of their misuse of funds led to few full investigations, but they made the PNG household in Cairns far more visible in both Australia and PNG than previously. While PNG-born residents were nearly invisible in the greater Cairns region, they became the focus of public speculations about their integrity.

Speculation and gossip by white Australians connected even Papua New Guineans who sought to live quietly, out of the public eye, to prominent Papua New Guineans and Australians. Most Papua New Guineans in the region make ordinary livelihoods and sustain quiet lifestyles so as not to draw attention to themselves in the mostly white Australian neighbourhoods in which they reside. However, their hope of a quiet life does not mean they wish to hide from their Australian neighbours. Indeed, they do not wish to live close to other Papua New Guineans. Rather than establishing homes close to their wantoks from the same village, province or workplace, new buyers aim to find property at some distance from them. They said they wished to escape other Papua New Guineans because they would make uninvited demands on their households, in the manner and style of wantokism. In Cairns, they hoped to escape the avarice they perceived as having come to permeate contemporary PNGvillage, settlement, suburb and town life. 
My own records show that keeping multiple residences was not specifically tied to an upper-income or upper-middle income group, and did not require large salaries. Many of the transnational PNG households in Cairns lack money; they keep very modestly priced houses in both Australia and PNG, counting among these even bush-material and rough-cut timber houses in villages where they or their parents were born. While some houses in PNG might be rented to family members, whose payments might help support mortgage payments in Australia, it is more common for relatives to live 'rent-free'. In such cases, a house is not an asset first and foremost but, rather, a means to provide for relatives whose own residence on clan grounds might offer a PNG-born migrant to Australia some hope of access to it in the future.

In the absence of better knowledge of PNG-born residents in Australia, most attempts to explain the census data generated moralising claims about the PNG community. In greater Cairns, councillors earnestly voiced support for the needs and interests of 'Papua New Guineans' residing in Far North Queensland; however, when counting them proved daunting, they soon gave up. Instead, they sought out individuals to represent Papua New Guineans on the multi-regional committee of local government. They accessed state funds for this, and invited several prominent PNG women to speak about the concerns of the PNG community in Cairns. Although the details of that work fall beyond the scope of this chapter, it proved to be a good plan of political action for accessing larger networks of PNG people.

I have reviewed the information derived from the census, and shown how that scant and speculative knowledge, assembled from what Thompson (1993) once referred to more generally as the gossip of quantitative data' (p. 413), is first comprised and then comes to effect PNG households. Therefore, an entirely different approach to understanding the transnational PNG household is called for. The idiom 'working other gardens', as used by some Papua New Guineans, shapes a wider ethnographic understanding of the transnational household by escaping the political and economic framework that girds the Australian census data and the many decisions about its use. For moral economy to provide the better bones to support the fully fleshed out sense that people make of their lives, I turn to marital and generational relationships in the household over several generations. As women and men remake traditional marriage 
arrangements for transnational lives, they must struggle to define the reach of affinal obligations and the change these bring to their access to traditional land.

My fieldwork in Cairns showed me how difficult it was to locate or even see Papua New Guineans in the geopolitical region, and revealed the complicated nature of the claim that they were part of a precarious political economy. Most Papua New Guineans do not have secure, ongoing access to traditional land in PNG; in any case, they worry that they might not enjoy the benefits of any livelihood that could be made from it. In addition, few PNG-born families own homes outright so the economic security of their household relies on a steady flow of money to repay mortgages. Many PNG-born women are unemployed, some by reason of their visa requirements as parents or guardians of children enrolled in Queensland schools, others because of lapsed qualifications and breaks in their employment as a result of their move to Australia. The security of the PNG transnational household relies on the wages of the husband, whether he is Australian or PNG-born, or on the businesses developed by PNG-born women with assistance from their relatives and access to traditional land at home. The latter provides only an irregular flow of money, as it requires long-term, ongoing negotiation with relatives. However, I argue that these are not signs that the moral economy is underdetermined by a new and precarious political economy. Instead, the moral economy is the very form and structure of the political economy of the PNG transnational household.

The moral economy of the PNG transnational household in Australia secures the moral, political and economic livelihoods of its members. It should not be contrasted abstractly to stability or instability in politicaleconomic terms, as scholars of industrial capitalism have done. This particular moral economy produces social life, and thereby encompasses political-economic factors. It is a moral, political and economic reality, and it is within this that the transnational household is defined by the practices of its members. They keep households in Cairns, at some distance from the jobs household members may hold in PNG cities and towns, and far from their PNG-based relatives, who make a living by horticulture and live in rural villages. They make long-term visits to relatives in PNG and to friends living in North Queensland and faraway in other parts of Australia. They say they feel more deeply and regularly connected to relatives in other Australian cities and in PNG than they do to their neighbours in their streets. 'Working other gardens' outside PNG, 
the paradoxes of their daily lives unfold as a moral reality of estranged relationships with some relatives, rather than a moral economy at odds with a political economy.

Therefore, the rest of this chapter examines the idea of a moral economy as a social reality, outlining the social norms of everyday living that inform the PNG household's search for the good life with relatives. The uses of the idiom 'working other gardens' highlight that the lives and livelihoods of transnational PNG households can be judged as moral realities rather than value-neutral statistical ones. In Durkheim's sense, it calls forth the sociological meanings of the division of labour in the traditional family and its extended kin, rather than an identification with the people of the deep history of Austronesian migrations across the Pacific, which was hinted at in the late-night storytelling that I described earlier as people contemplated what they had lost in their migrations south. Different from the census data, my ethnographic research shows that it is not the historical 'waves' of migration as such (from those of the colonial period to independence to the present) that shape the transnational PNG household. Rather, in the late twentieth century, the PNG transnational household is shaped by patterns of marriage, both by relationships with marriage partners who think of themselves as wantoks, 'speakers of the same language', and with those who do not come to the marriage as wantoks.

\section{'Working Other Gardens': Creating Solidarity in Transnational Households}

Details of households founded on marriages between PNG women and non-PNG men, and PNG women and men from different regions of PNG, show how most people struggle to keep alive traditional forms of access to land, even as they are 'working other gardens' outside PNG. Traditionally, women access garden lands through marriage, usually following their husbands to work on the land he can claim to access from his clan. Some women retain access to the gardens of the clan into which they are born. Generally, it happens that a woman loses access to muchwanted gardens by making a marriage to a partner who has none, and even risks losing access to gardens of her clan when clansmen distrust her use of the gardens after making a non-traditional marriage to either a non-PNG man, or a man from another region or language group in PNG. The loss is made more profound when, as happens to some families, a woman's son 
and daughter are denied access to gardens by clansmen of their mother, who would otherwise assist them with accessing the land and cultivating it. 'Working other gardens' is an idiom deeply rooted in the traditional relationships between systems of kinship and land tenure, and the sense of the idiom is strengthened by knowledge of the matrices of marital and generational relationships that I set out in this section of the chapter.

\section{Marriages Between PNG and Non-PNG Spouses}

The older generation of PNG-born women who migrated to Australia in the 1970s came predominantly as the wives of men of non-PNG descent (usually white Australian or white European, but often Chinese). Their marriages were celebrated in vastly different ways: either according to the traditions of the wife's clan, by legal register or in church ceremonies. Even today, there are lively discussions in PNG transnational households about the making of marital unions, and these can help clarify the different investments people have made in the process. Many tales are told of trucks and household appliances being given as one-off payments of bride wealth. There are many stories too of situations where an individual white Australian man, on the advice of his PNG wife, made a traditional offer of a gift of bride wealth to her clansmen, but with a non-traditional sensibility. Often the aim was to give generously so that the wider network of relatives could enjoy, and even share the bride wealth with the entire clan, and even the entire village. Such was the case of one husband who, after his children were born, sent a shipping container of school equipment (desks, boards and books) to his wife's village in Milne Bay to thank it for his family, which he called 'the best gift they could have given him'. However, many Australian men married to PNG women who made one-off gifts of money at the time of the marriage never sent anything more, as they had 'completed the bride price payment'. Others, in choosing a 'church wedding', refused to enter into customary marriage exchanges from the outset.

Most Australian husbands who did not originally make bride wealth gifts have not maintained ongoing relations with their wife's relatives, although the wife will often do so. It is her choice whether to support her clansmen. Some women with businesses in PNG use their profits to support clansmen in their village. One woman I knew operated an arts and craft business selling her relatives handwork, in particular, bilums (net bags), to international customers. Her business also moderated the loss to her husband's salary from contributions to her clan sisters' households, 
gardens and children's school fees. Several women with personal wealth supported natal kin without their husband's knowledge, but the majority of PNG women married to Australians do not have the personal means to do so.

These Australian-PNG households form a loose social network. They meet annually to celebrate PNG Independence Day and milestone events in the life of the household. Those who have lived in Australia for a full generation come together to join in retirement parties and birthdays, or to attend the funerals of old friends, who always seem to have died 'too young'. Conversations are peppered with memories of past decades when people lived in the towns of what were then the Territories of Papua and New Guinea. It is not clear that they will reproduce their community by these measures, but they are creating a bank of memories for use in the future.

\section{Marriages Between Spouses from Different PNG Regions}

A younger generation of PNG women and men are moving south in the twenty-first century to educate their children in Australian schools. They form households founded predominantly on marriages between PNG men and women from geographically and culturally distant parts of PNG. Some of these marriages are recognised in PNG law as traditional marriages, where bride wealth is arranged by the husband's family and received by the wife's kin, but others are not. In most cases of traditional marriage, people debate the social norms and come to an agreement about what 'feels right', with the husband agreeing on an arrangement for a gift to his wife's parents, which they accept as his bride wealth payment. Many choose to have a religious ceremony in a PNG church; alternatively, some ask a magistrate to perform the marriage in his office. Sometimes, couples ask for a church blessing by a priest or pastor, who will perform a ceremony for couples who have lived for many years as husband and wife with their children in a 'traditional marriage'. Some couples insist that church weddings still meet all the obligations, given that traditional practices are diverse and unclear, especially when the two parties hail from places as distant as Manus and Milne Bay. In both cases-traditional and non-traditional-a man will seek to have his marriage registered by a magistrate, who provides the legal record to accompany a couple's migration to Australia. 
For these younger migrants to Australia in the twenty-first century, the choice to work in Australia is not simply about salary. They have few opportunities in PNG to advance their livelihoods, largely because it is unusual for members of this educated younger generation to have easy access to clan lands for gardening or businesses. Some are involved with their clanspersons in larger financial enterprises, but they are frequently subordinate partners to relatives who hold elite jobs in Port Moresby and who keep close relations nearer to the villages and land of their birth. The transnational family member with a firmer foothold in PNG generally claims clan land for business ventures and the economic development of their village. Most of this generation of PNG migrants to Australia have much more fragile connections to clan land.

Working in Australia provides this generation with the only real way of advancing their lives and those of other members of their greatly dispersed households, as waged professional employment is the only way they can make a living. They say it became clear to them in their school days that educational success would be the product of their own hard work, and that schools and workplaces would be their 'gardens', as they lacked access to land. They rely extensively on non-PNG workmates, often because their marriages were not made in keeping with the traditions that would solidify their affinal relations. Usually the spouses come to Australia together, each having had an independent career in business or the professions. However, in finalising their migration to Australia, one, usually the wife, foregoes their career to relocate.

This generation of PNG-born migrants to Australia is not as closely tied to affines by traditional marriage as their grandparents or greatgrandparents' generation, but they do maintain commitments to sustaining their siblings and parents in PNG. Thus, the habit of sending remittances to their village-residing kin is common. They remit money, automobile parts, used clothing and traditional arts and crafts, including a small number of cowrie shells, but they do this when and for whom they choose. Their generosity towards some of their clanspersons is recognised and welcomed, and their record of giving is only a bit less unreliable than that of the older independence-generation women. Most maintain an attenuated correspondence with relatives by telephone and email, largely because they have discovered that they can control how they use and give their free time. I have been with PNG women many times when their mobile phone has lit up with a PNG number. Usually, the caller, short 
of credit, asks 'auntie' for a call back. The women have the choice of not picking up, and they often let the phone ring out. I learned that it is common to receive answering machine and text messages, but the PNGborn woman usually chooses to return them later, not immediately.

A comparison of the two different generations of migration shows common patterns. As noted, the first migration of PNG women occurred with the repatriation of their husbands who were colonial agents at the time of independence. The second occurred with the movement of PNG families redeployed to an Australian subsidiary of a company employing them in PNG. These later migrations, which allow the continuation of work and education in Australia, are made under employment policies agreed by multinational mining companies and the Australian Government. Notwithstanding the political and historical differences between the two waves of migration, the transnational PNG household in both eras has rested on common ways of reorganising relationships to accommodate PNG traditions in a different land and, in that sense, both sets of PNG migrants have 'worked other gardens' than the households into which they were born.

It has been the practice of members of both waves of migration to send material goods to relatives in PNG; this in a common pattern of giving to clanspersons. Typically, individuals in both waves of migration have sent monetary and non-monetary gifts to their clanspersons. In the first wave, it was the women who did this; their Australian husbands did not send remittances. In the most recent wave of migration, I have found that both PNG women and men send remittances to clanspersons. Like Australian spouses of PNG women, they do not send gifts to the clanspersons of their spouse, their affines; instead, like the PNG women of the previous generation, they send money and goods to their clanspersons. With only a few exceptions, neither PNG nor Australian men choose to send gifts of ceremonial shell wealth and money onwards to their wives' brothers to complete bride wealth payments, as they would have done in past years.

The tradition of arranging for the gift of bride wealth from the husband's to the wife's clanspersons has not been present in either migration. However, there has been innovation of that custom to assert the legality of marriages. In most cases, the bride wealth is given once, in the very early years of the marriage, to the wife's parents only. Few gifts of bride wealth are made to them after that ceremonial gift. Where affinal relations are 
honoured or recognised by exchanging traditional forms of bride wealth at the time of the marriage, no one believes these imply an ongoing interdependency in making a livelihood, as would be the case in a village sustained by horticulture. While these innovations in giving bride wealth symbolically solemnises, and legally secures, traditional marriage, it does not become a basis for either Australian or PNG men to continue to give gifts to their wives' relatives, either to complete traditional bride wealth payments, or to contribute to the livelihoods of affinal relations.

\section{'Working Other Gardens': Estrangement from Traditional Land}

Estrangement is a relationship, one that does not require that the partners to it believe in their absolute alienation from shared resources. 'Working other gardens' captures the sense in which the transnational PNG household exists even in the absence of some marriage partners' access to clan lands. In this section, I investigate the nature of estrangement from clan lands and gardens typical of the transnational PNG household. My ethnography shows the moral paradox that grounds it; the PNG household rests on the solidarity created through international remittances and on the estrangement that is felt by people who no longer work together in gardens made on their clan lands. Here, I am concerned to show how that moral paradox shapes the household's history and its present.

There are three ways in which the transnational PNG household emerges as a social unit for 'working other gardens': first, through the loss of access to traditional lands used to support non-traditional economies and means of creating wealth; second, through long-term, multi-generational neglect of payment of bride wealth; and, third, through marriages made across cultural and linguistic groups with very different patterns of inheritance. Case Set 1 shows households constituted by traditional and non-traditional marriages under conditions where land has been used for non-traditional purposes. Case Set 2 shows what I interpret as symbolically constructed wantok households constituted by marriages made without strong commitments to meeting clan-wide obligations to bride wealth gifts, and often in the absence of shared traditional practices for these. Bride wealth in these cases is used to legalise a marriage for the Australian immigration office, or to solemnise it with the symbols of tradition. Case Set 3 shows non-wantok households constituted over 
several generations by marriages made between men and women who are not of the same language group and, thus, have come to have no access to clan lands through their marriages, as well as a fragile relationship to clan lands through their descent from parents from different regions and language groups.

\section{Case Set 1: Traditional and Non-Traditional Marriages, Estrangement from Land}

The first set of case studies shows marriages between wantoks that have been made according to tradition. Nevertheless, some of their kin have agreed to pass clan lands into non-traditional use, and have thereby excluded other kin from access to it. Clanspersons are excluded when the land is harnessed for use in primary resource extraction, preventing horticulturalists from enjoying its use for gardening. They are also excluded when land is degraded by timber extraction or following over cropping for corporate or industrial agriculture. In these cases, clanspersons' access to garden lands remains secure, but the means of gaining a livelihood from the gardens does not.

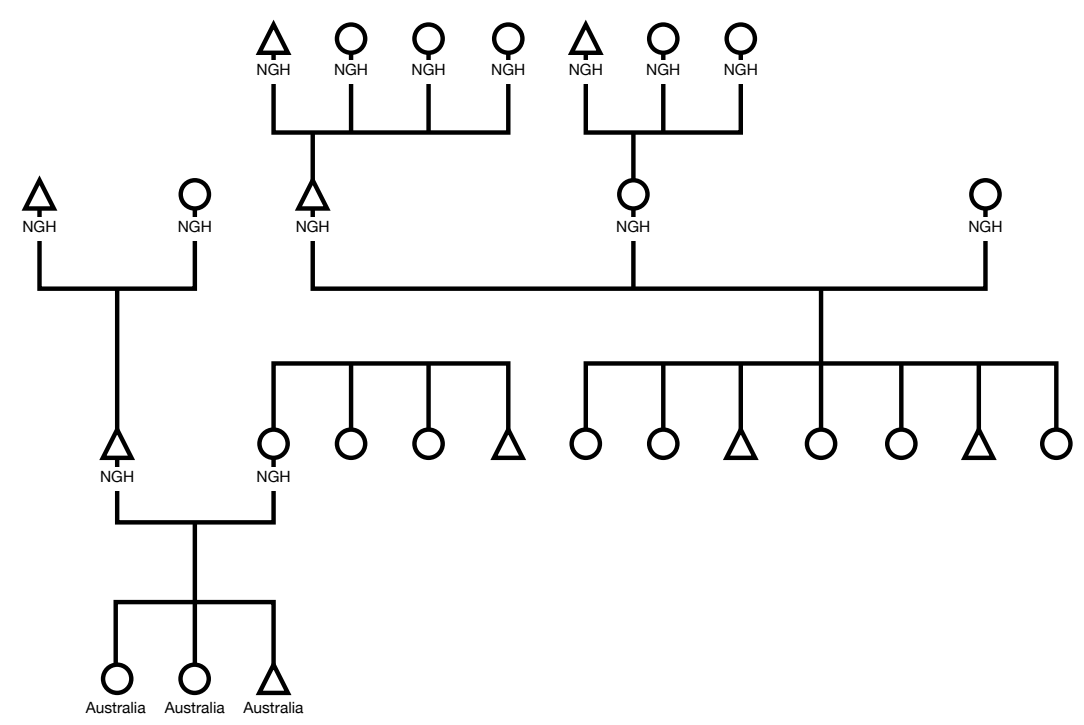

Figure 6.1: Traditional Marriage, While Land is Under Development Key: Triangle = male; circle = female; horizontal link below = marriage; horizontal link above $=$ siblings; vertical link $=$ descent.

Source: Fieldwork data. 
In Figure 6.1, which shows three generations of a household in a coffeegrowing region of the PNG Highlands, the residence of different members shifts over the years. The eldest generation, all of whom were born and lived a lifetime in the New Guinea Highlands, planted the coffee and benefited from the crops. The second generation were educated on the profits from the coffee plantations and found work in provincial capitals, as well as Port Moresby, after training to become health and education professionals in PNG during the time of independence. The household genealogy shows that they were born and married in different places across the country. The third generation attended tertiary education institutions and hold degrees. They arrived in Australia in the same decade that the coffee plantation failed to bear profits to support their lives in their home region. Citing violence between household and clans as a reason for leaving, and prepared to make their livelihoods while employed on company contracts with a mining company, these families say that their careers in Australia are 'their only remaining gardens'. In short, they are saying that they are environmental and economic refugees seeking a substitute for making a living from horticulture.

Figure 6.2 shows marriages that, over several generations, have alienated relatives from one another. Not surprisingly, these marriages have been made between Papua New Guineans and 'Europeans'-for the most part, white Australian. Of the two cases from this set that I have chosen to discuss, one stands out for its depth of knowledge about the generational history of a family. It links the household history of a marriage in the early colonial era, between a German man and a New Guinean woman and, a decade later, between an Englishman and a Papuan woman. After World War I, the German father was repatriated and the wife remarried a man of 'mixed ancestry' from the south coast of the Territory of Papua. Subsequently, the children of the family were split between the Territory of New Guinea, Germany and Australia. In the second generation, each of the children experienced difficulties just making their marriages and in finding land to settle on. In the period between the wars, social norms dictated that people of 'mixed race' would be treated as undesirable marriage partners unless they were in regular employment. Relatives often refused bride wealth from 'mixed-race' men, sometimes even if the man had the means to make a bride wealth payment. They did not marry according to tradition; rather, most marriages of this kind took place in the church. 


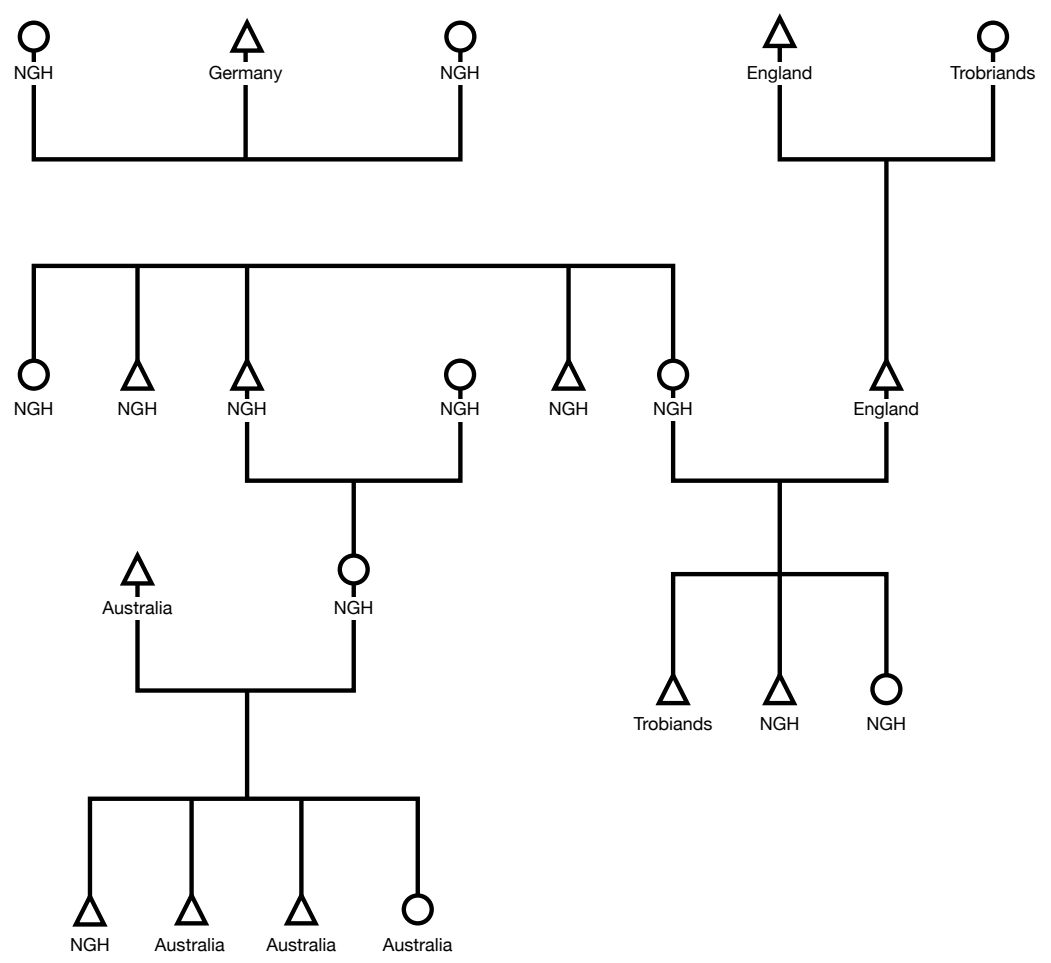

Figure 6.2: Non-Traditional Marriage, Changing Residence

Key: Triangle $=$ male; circle $=$ female; horizontal link below $=$ marriage; horizontal link above = siblings; vertical link = descent.

Source: Fieldwork data.

Over the next two generations, siblings and cousins sent letters to each other and sought to reconnect. The household established in Cairns today provides a point of connection for some of the members. Some of the large, loosely related household members identify with the clans from which they might descend, but this is voiced as a memento of their history, not as evidence of a relationship to that clan or as claims over ownership of clan ground. No members of this household have claims to land in PNG, as so few of their marriages were made according to the traditions that normally would secure access to it. 


\section{Case Set 2: Innovative Bride Wealth, Uncertain Access to Traditional Land}

The second case set concerns innovative marriages that are not recorded as customary. Figure 6.3 records the history of two generations descending from the marriage of a PNG woman to a New Zealand man. A member of the wife's birth mother's clan adopted her at the age of five. Her adoptive parents educated her, and she acquired a certificate to teach in secondary schools. She did not remit money or gifts to her mother's clanspersons in the village in the years during which she drew a salary for her work as a teacher in PNG. However, she did send money to her father, who was of a different clan than she was, as he had paid her school fees. Now she sends money to her brother and her mother's clanspersons in her village of birth. Her husband reports that he never knew her birth parents, and that her adoptive father did not want to receive bride wealth. He believes sincerely that a gift should be given as if giving a part of himself; he does not wish to give to people he has never met and who did not raise his wife as their daughter. The children of the marriage are young adults who have no claim on land in PNG because the family says that the father did not marry the woman according to custom.

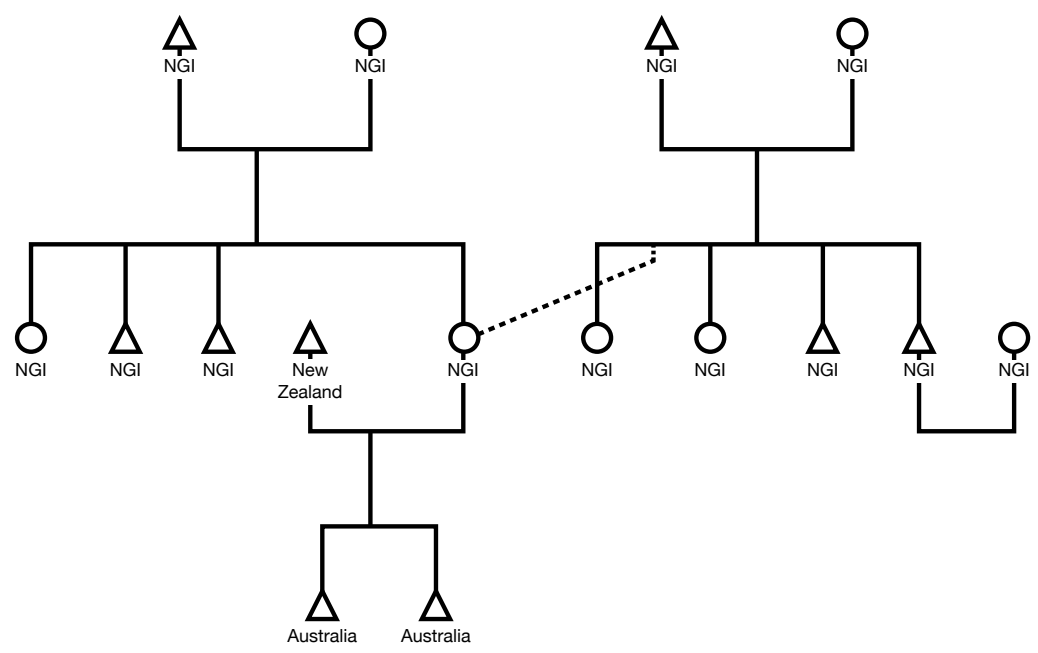

Figure 6.3: Non-Traditional Marriage, Including Traditional Adoption Key: Triangle = male; circle $=$ female; horizontal link below = marriage; horizontal link above = siblings; vertical link = descent; dotted line = adoption.

Source: Fieldwork data. 
What is interesting in Figure 6.3 is how misunderstandings about the history of the wife's parentage and failure to make gifts to key relations attenuated her claims on clan ground while also solidifying her potential claim on it for her sons. Over the 30 years of their marriage, her husband paid to have a house built for her adoptive brother. She had urged him to do this after her parents died, and he had agreed because he liked the idea that a modern house would be more comfortable for him on the annual visits that he and his wife made to her birth village. However, despite her gifts, the woman still struggled to assert any claim on her clan's ground. Her husband had acted without understanding the gift part of a traditional ceremonial exchange, and had thereby unwittingly married his wife by traditional rituals of the exchange of labour. When an accident occurred and his adoptive brother-in-law died suddenly, he assumed he had lost his advocate for access to clan grounds, but he had not. His wife continued to make a case for him.

There is an irony here; it lies in the fact that because a woman from her own clan had raised her, and because, by PNG law and by her local custom, her mother's sister is also her mother, the woman was a member of both her mothers and her brother's clan by matter of her birth to her mother and her adoption into her mother's sister's clan (the same), which are both conventional ways of affiliating members to a matrilineal clan. A deeper irony lies in the fact that bride wealth normally is given from the husband to the brothers of the wife, rather than to her father or mother, and this woman's husband did exactly that by building a house for his brother-in-law. In short, her relatives did not recognise the house as a form of bride wealth, largely because her husband had made it in accordance with his intention to give them a gift, and not in accordance with their requirements that ceremonial exchange of traditional bride wealth meet their expectations.

\section{Case Set 3: Bride Wealth Household Solidarity and Estrangement from Land}

The third set of case studies shows marriages between PNG men and women from different parts of PNG, for whom regional differences in place of birth means they were not wantoks before marriage. The example is that of a household founded on a marriage between a man from Port Moresby and a woman from Lae. They are the children of parents who lived and worked in different regional capitals. He was the son of man 
from Rabaul, where (matrilineal) tradition rules that individuals gain access to ground by way of their mother's claims on it, and of a mother from the Highlands who had been working as a nurse in the provincial capital and whose clan's (patrilineal) tradition rules that individuals gain access to gardens by way of their father's claims on it.

In the case of the husband, neither of his parents had secured traditional access to clan lands in the regions of their birth. They were children of marriages in those regions that did not give them simple access to clan lands by way of clan membership. In addition, the careers of his parents and grandparents' generation took them to different regional centres and away from the opportunities they needed to establish access to clan grounds by working alongside their cousins and winning respect for their efforts to meet traditional obligations. The wife of the household was the daughter of a woman from Bougainville, where civil war had prevented her return to develop clan grounds, and of a man from the Trobriands who could not easily pass on land to his children without disrupting his relationship with his younger clanspersons, who were his nephews and nieces. In the past, her grandfathers had married spouses whose offspring would not have ease of access to the clan land of their mother. She had no claims on land through either her grandfathers or grandmothers.

Members of households founded in marriages made across such great social and traditional differences say they do not even begin to consider how they might access each other's gardens. Neither do they believe they have claims to the clan grounds of their respective parents; custom prevents transfers of access to gardens for the children of men or women who are not clanspersons or wantoks of the traditional owners. Working gardens in PNG is impossible for the couple I knew, although their PNGresident kin recognised them as members of their large and complex transnational household by accepting the bride wealth gifts that the man offered. In such cases, bride wealth is 'only symbolic' and is inadequate for the work of winning access to garden lands. Poignantly, the husband commissioned a portrait of his wife adorned in traditional bride wealth, but she had never worn such wealth, neither for her marriage nor for her sittings with the artist.

The children of marriages similar to the example given in Figure 6.4 cannot make direct claims on clan grounds, and will not do so in later years. Instead of trying to access garden lands, or trying to form businesses with clanspersons in PNG, they imagine that a better future for themselves 
and the next generation of their wholly PNG family exists overseas. One such family chose to resettle in Australia from Port Moresby. They hope, over the course of the next 10 years, to finish their obligations to living relatives, thereafter ceasing to make any ceremonial gifts to kin. Summing up their perspective on the value of meeting their obligations through ceremonial exchange, or through remittances, the couple asserted that it is 'just a waste of money that we need for the household'.

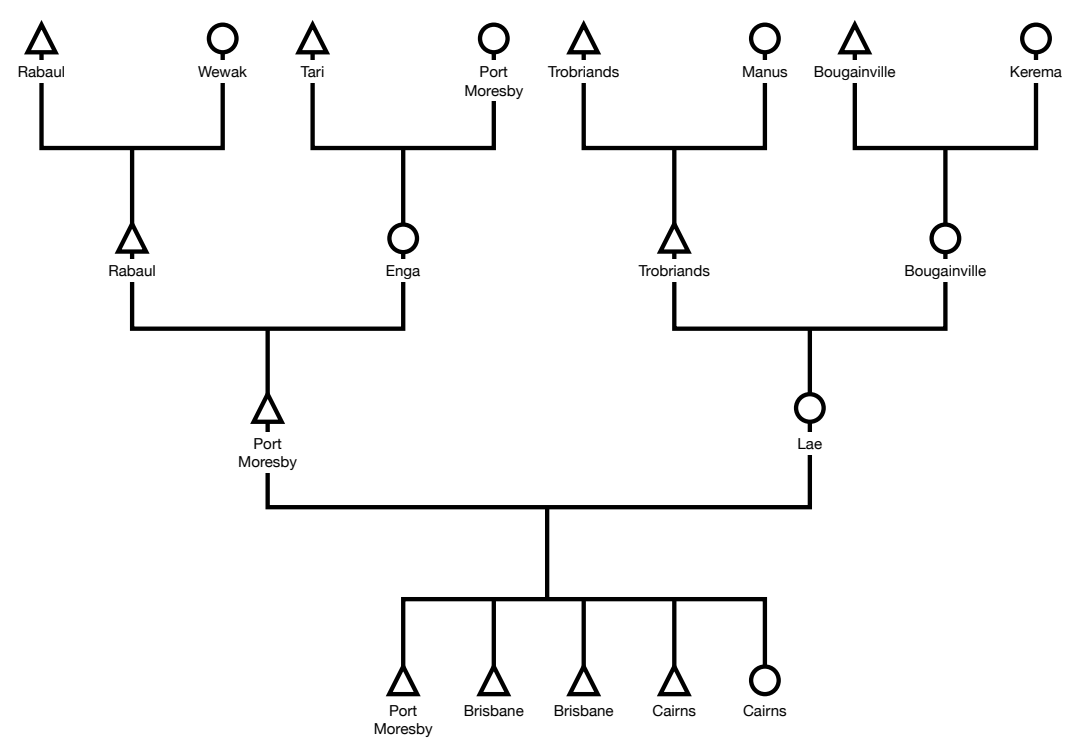

Figure 6.4: Marriage Across Regions Occurring over Four Generations

Key: Triangle = male; circle $=$ female; horizontal link below = marriage; horizontal link above $=$ siblings; vertical link $=$ descent.

Source: Fieldwork data.

All three case sets show that meeting obligations to give ceremonial wealth for marriages, or sending remittances as gifts to clanspersons, is a means for creating a sense of solidarity through the work of making exchanges happen. However, all cases show as well that the same ceremonial wealth and remittances give no assurance that the givers of either form of wealth will not be estranged from the clan lands in which they might have hoped to share, should the receivers of the gifts choose not to recognise it as fitting. Access to land is not ensured; however, members of the diaspora do not live in alienation from their lands, even when estranged from relatives who live on clan grounds. As this moral reality unfolds, the transnational PNG household might turn elsewhere than PNG to satisfy its search 
for ways to create a good life with its members. At the same time, such households might well keep their link to their country of birth and to kin who do make livelihoods on clan ground.

Papua New Guineans in Australia say that while they are living outside PNG they are 'working other gardens'. Although migration raises opportunities to reflect deeply upon what has been left behind, the idiom does not simply refer to the loss of gardens and their replacement with skilled and professional work in jobs overseas. It is certainly the case that there are many reasons that transnational Papua New Guineans cannot access land, including regional conflict, long-term leasing to resource extraction companies, environmental degradation after years of misuse of soils and obstruction of people's use rights to traditionally owned land. However, none of these experiences of loss of gardens fully embrace why or how they come think of work-life in Australia as 'working other gardens'.

The Papua New Guineans who taught me about their way of making a livelihood said that 'working other gardens' is a new form of 'powerful speech', a complex idiom that carries the sense of the quality of social life created by work. Beyond the obvious meaning of 'working abroad' or 'working overseas', their work is often directed towards the goal of creating a good livelihood, and provides them with a rationale for attending to social norms even as they seek to realise their individual hopes. 'Working other gardens' is a metaphor. The phrase grasps both the moral economy of working other gardens, and evinces the sensibility of a political economy in which they must work others' gardens. There is ruefulness in their tone; as they shared their bitter humour about the conditions of living transnationally in that evening's gathering in northern Australia, the idiom 'working other gardens' took on new meanings. Replacing 'other' as an adjective meaning 'different' with a plural possessive pronoun connoting 'dispossession' creates a revolution in their understanding of social life, one in which solidarity with others becomes uncertain, and accompanies estrangement from others as a mobile, or uneven, moral reality unfolds in the transnational PNG household. 


\section{The Moral Economy of 'Working Other Gardens' as Moral Reality}

My conclusions, drawn from interviews with 60 PNG households with residences in Australia, have been analysed as four distinct claims. First, the PNG household is distributed across several nations, and is, therefore, transnational. Second, the PNG household comprises relationships by marriage with those who are not Papua New Guinean by descent as well as those who are, and relationships by friendship with those who are committed to household solidarity. Third, marriages in the PNG household constitute the moral reality of the household by enhancing its solidarity. Fourth, that solidarity is won with the household member's recognition of their deepening estrangement from traditional access to land in the homeland. Finally, having analysed the ethnography of the transnational PNG household, it is possible to interpret the conversation I introduced at the beginning of this chapter to comment on the insights won with an ethnographic approach to moral reality.

In introducing the transnational PNG household, I conveyed the sense that contemporary movement across the Coral Sea to 'work other gardens' is difficult for reasons quite different from the ancient fear of rough crossings. In the twenty-first century, the narrowest crossing of the Torres Strait between PNG and Australia is a shallow passage that can be traversed easily by boat. Flights between Cairns and Port Moresby leave every two hours, and those between Brisbane, Sydney, Melbourne and PNG's national capital are nearly as frequent. However, travellers must give good explanations for their coming and going to immigration officers in Australia. Papua New Guineans who are now Australian citizens hold hard-won PNG work visas in their hands. Immigration officers inspect carefully secured temporary residency permits and permanent residency papers; the Papua New Guineans I spoke with were increasingly finding that work movements and bureaucratic difficulties in securing documents in PNG were taking a toll.

Papua New Guineans in Australia feel a growing frustration and anxiety about the restrictions on their movement. Over the course of an evening with a half-dozen PNG men and women in Far North Queensland, I heard them complain about the various contemporary visas, which they described as impediments to ease of movement and as detrimental to the quality of living for members of the transnational PNG household. 
They also spoke about how the many Australian investments in PNG terribly affected the PNG environment. Industrial effluent had damaged some PNG coastal waters. Only in the previous week, some of those newly arrived in Australia by boat from PNG had seen silt from mining operations emptied into a harbour, making its shallows difficult to navigate. They considered this a tragedy.

After a brief pause, followed by a heavy sigh, one man made a loudly spoken observation that it looked like 'the land bridge will rise from the sea again to link PNG and Australia' as a result of damage from Australian mining in PNG. He smiled. Although this was certainly a bitter sense of humour - seeing a long-term positive in an environmental disaster-the group erupted with laugher. They surmised that soon they would be able simply to walk across the narrowest parts of the Torres Strait and arrive in Queensland. 'Forget airplanes, boats and visas. The countries of PNG and Australia will be one whole place again', and Australians and Papua New Guineans will live on the wretched earth together. For some time after, people wiped tears of laughter from their eyes while they repeated to the room that the land bridge once present between New Guinea and Australia would rise again, and 'everyone can walk on that bridge to find our pre-history'. Their joking played with the ordinary historical account. Instead of looking to the past, they gave a tragicomical account of how they had come to be where they were now 'working other gardens' in Australia, distant from the clan-owned lands and gardens they had left behind.

How people recount the ways in which they come to live with each other reveals much about their identity and also provides a record of the moral reality of their present and future social actions. The anthropologist, like the historian, finds many ways of telling and writing other people's shared experience. One example is the work of anthropologist turned novelist Drusilla Modjeska. In The Mountain, Modjeska (2012) uses literary devices to create a novel peopled with compelling characters imagined through the details of the lives of the complex personalities who led PNG to independence in the mid-1970s. Another example is that of journalist Sean Dorney (2016) who has called for better contemporary history of the deep association between PNG and Australia, including Australian involvement in PNG's recent political and social tragedies and triumphs. The retired parliamentarian Carol Kidu (2014) has called half a century of international relations between Australia and PNG a 'gentle history' 
of individual people in families, schools and shared work. Here, I am concerned with the moral reality expressed as 'working other gardens' by which people share in each other's interests in a good life together.

In this chapter, I have described idiomatic usages of the notion of 'working other gardens' to capture its centrality in the many levels of the contemporary moral economy. I have shown how the ethnographic idiom 'working other gardens' captures the reality of the twenty-first century division of labour that defines the PNG transnational family's solidarity and estrangement today, yet ties this family to abiding moral qualities of PNG-village life thriving on garden work. I used their insight into the power to make sense of their contemporary experience in ancient ways by describing it as 'working other gardens' in contrast to how their residence in Australia is accounted for in the analysis of 2011 Australian census data. The sense of the idiom shaping household solidarity is found in the social and moral core of the political history of migration, which I show is shaped by the legacy of marriages of PNG women to non-Papua New Guineans, or to Papua New Guineans from different regions of their country. The third sense of the idiom, found in their estrangement from traditional land, is revealed in close analysis of bride wealth payments made by men who were not members of the same language group, or wantoks, before marriage. For them, the consequence of paying bride wealth inappropriately has meant that both they and their children have been estranged from clanspersons and clan lands.

The different uses of the idiom show that 'working other gardens' is a 'moral fact' (Karsenti, 2012) in Durkheim's sense; that is, it reproduces the material social conditions that sustain the idea of a good life as they work to realise it. In classical anthropological terms, moral facts, like those expressed by the idiom 'working other gardens' and working as a form of practical reason, exist as the very ground of people's livelihoods, displacing any notion of the primacy of utilitarian or ends-based reasoning. Durkheim, and those working in his legacy (Evans-Pritchard, 1937; Mary Douglas, 1973) have been much criticised for failing to distinguish the social from the moral life (see Howell, 1996). However, others believe that an upending of this criticism is overdue because it has obscured the strongest points of Durkheim's (1984/1933) early book, The Division of Labour in Society (see Fassin, 2012). After Durkheim, anthropologists could claim profound understanding of the grounds for speaking of society, and for reflecting on how a good life is shared. To grasp the importance of Durkheim's early studies of morality, one must contemplate the more provocative question of what people intend when 
they up stakes and move to unknown places. This chapter works critically within that tradition, revealing the moral reality of the transnational PNG family by describing how its members are 'working other gardens' as the ground of both their solidarity and their estrangement.

Thinking of 'garden work' as an ethical and aesthetic claim to relations that span seas and land is not new in the region. When Malinowski (1936) wrote in Coral Gardens and their Magic (his most significant volume on the Trobriand Islands, to the south-east of mainland PNG) that the aim of gardening was to make good yams to give to others, he was asserting the nature of moral reality. In later years, Alfred Gell (1999) reminded us that good yam gardens are also beautiful because they make food available to others to eat. Working a good garden means creating a good life together; thus, seeing a good yam could come to be attractive to anyone. However, the transnational PNG household is also estranged from those kin who are landowners. This too is a moral fact.

By working other gardens, the transnational PNG household emerges as a fact-a moral reality. Karsenti (2012) called on a theory of moral reality in his insightful Kantian reading of Durkheim's (1984/1933) work, exploring the revolution in moral philosophy as an event with the power of a bomb dropped on the ground of economic reason. For Karsenti, Durkheim revolutionised scholarly knowledge about the grounds of society by showing how they exist in human moral judgements, as well as in the prescriptive social norms that such judgements make and challenge. Morality is not to be studied as philosophy, but rather as a reality people make. For Durkheim, and for those who have worked critically within the legacy of his work, morality is a living, unfolding moral fact, and not just a social norm instituted by the ideal of a distributive morality in liberal democracy (for a different interpretation see Giddens, 1971). Accordingly, the living moral fact is constituted by crossing the gap between the sanctions raised against moral and legal infractions and the individual desire to 'do good' (Karsenti, 2012, p. 23) because neither the rule nor the collective desire for the good is a satisfactory definition of morality in itself.

A moral economy of the transnational PNG household exists at the level at which 'reality unfolds as actions and judgments of actions' (Karsenti, 2012, p. 35) —as the ethnography of moral reasoning (Sykes, 2009)— where words become deeds and social actions become important for their capacity to capture contradictory processes. With a sustained description 
of the idiom 'working other gardens' as a point of critical reflection and political action, this chapter captures the transnational PNG household's understanding of the division of labour in society. It explains PNG households' sense of estrangement, as much as solidarity, at the very least in the sense that 'other gardens' are others' gardens, and not fully possessed by the gardener working them.

\section{References}

Dalton, N. (2014, October 25). 'Island states' buyers love Cairns. Cairns Post, p. 13.

Department of Immigration and Citizenship. (n.d.). The PNGBorn. Canberra, ACT: Government of the Commonwealth of Australia. Retrieved from www.dss.gov.au/sites/default/files/ documents/02_2014/papua_new_guinea.pdf

Dorney, S. (2016). The embarrassed colonialist: A Lowy Institute paper. Canberra, ACT: The Lowy Institute, Penguin Specials.

Douglas, M. (1973). The logical basis of constructed reality. In M. Douglas (Ed.), Rules and meanings: Essays in the knowledge of everyday knowledge (pp. 23-70). Oxford, England: Routledge.

Durkheim, E. (1984). The division of labour in society (E. Halls, Trans.). New York, NY: The Free Press. (Original work published 1933).

Evans-Pritchard, E. E. (1937). Witchcraft, oracles, and magic among the Azande. Clarendon, England: Oxford.

Fassin, D. (Ed.). (2012). Moral anthropology. Oxford, England: Blackwells.

Gell, A. (1999). The art of anthropology: Essays and diagrams. New Brunswick, NJ: Athlone Press.

Giddens, A. (1971). Capitalism and modern social theory: An analysis of the writings of Marx, Durkheim and Max Weber. Cambridge, England: Cambridge University Press. doi.org/10.1017/CBO9780511803109

Howell, S. (1996). The ethnography of moralities. London, England: Taylor and Francis. 
Karsenti, B. (2012). Durkheim and the moral fact. In D. Fassin (Ed.), A companion to moral anthropology (pp. 19-36). Oxford, England: Blackwells.

Kidu, C. (2014, 3 November). The importance of people to people relationships between PNG \& Australia. Australia-PNG Network. Retrieved from auspng.lowyinstitute.org/publications/importancepeople-people-relationships-between-papua-new-guinea-australia

Malinowski, B. (1936). Coral gardens and their magic (Vols. 1 \& 2). London, England: Routledge.

Modjeska, D. (2012). The mountain. Sydney, NSW: Vintage Australia.

Sykes, K. (2009). Residence: Moral Reasoning in a Common PlaceParadoxes of a Global Age. In K. Sykes (Ed.), Ethnographies of moral reasoning: Living paradoxes in a global age (pp. 3-40). New York, NY: Palgrave. doi.org/10.1057/9780230617957_1

Sykes, K. (2013). Mortgaging the bridewealth: Problems with brothers and problems with value. HAU: Journal of Ethnographic Theory, 3(2), 97-117. doi.org/10.14318/hau3.2.007

Thompson, E. P. (1993). Customs in common. New York, NY: The New Press. 
This text is taken from The Quest for the Good Life in Precarious Times: Informal, Ethnographic Perspectives on the Domestic Moral Economy, edited by Chris Gregory and Jon Altman, published 2018 by ANU Press, The Australian National University, Canberra, Australia. 